\title{
STUDI ANALISA KAPASITAS DEBIT TERHADAP KEBUTUHAN AIR BERSIH PROYEKSI TAHUN 2009 - 2014 PADA IPA BANTUAN OXFAM (PDAM TIRTA MON PASE) KABUPATEN ACEH UTARA
}

\author{
Susilah \\ Jurusan Teknik Sipil, Fakultas Teknik, Universitas Malikussaleh
}

\begin{abstract}
Abstrak
Kabupaten Aceh Utara terdiri dari 27 kecamatan dengan jumlah penduduk 541.878 jiwa. Ditinjau dari aspek kesehatan masih sangat minim, terutama mengenai pemenuhan kebutuhan air bersih untuk sehari-hari. Di sisi lain pemerintah daerah belum mampu untuk memenuhi air bersih terutama pada desa- desa yang ada di kecamatan dalam kabupaten Aceh Utara. Pada tahun 2008 yang lalu NGO Oxfam memberikan bantuan berupa Instalasi Pengolahan Air (IPA) yang berkapasitas 20 1/dt terletak di desa Geudong dengan wilayah pelayanan di dua kecamatan yaitu kecamatan Meurah Mulia dan kecamatan Samudera kabupaten Aceh Utara. Kebutuhan air bersih dari tahun ke tahun menunjukkan tingkat kenaikan yang cukup besar. Dengan adanya tingkat kenaikan tersebut maka dapat dibuat suatu skenario terhadap alternatif proyeksi pemenuhan kebutuhan air bersih dengan melakukan evaluasi terhadap kapasitas produksi, kapasitas konsumsi, kapasitas debit, serta pertumbuhan jumlah penduduk. Pengumpulan data dilakukan dengan berbagai cara antara lain melalui studi literatur, mencari teori-teori yang mendukung penelitian, mencari data-data yang diperlukan di instansi-instasi terkait, observasi lapangan dan bertanya langsung dengan sumbernya. Data yang telah terkumpul kemudian dihitung menggunakan beberapa metode antara lain metode Haspers dan metode Gumbel untuk menghitung curah hujan rencana agar mendapatkan nilai debit andalan. Sedangkan pertumbuhan jumlah penduduk digunakan tiga pendekatan metode yaitu metode Arithmatik, Geometrik, dan Least Square. Debit andalan sungai Krueng Pase diperoleh sebesar 7,765.911 $\mathrm{m}^{3} / \mathrm{det}$, untuk perhitungan laju pertumbuhan penduduk diperoleh sebesar 42436 jiwa, dan kebutuhan air bersih sebesar 112,603 1/d. Maka dapat diambil kesimpulan IPA Bantuan Oxfam berkapasitas produksi 20 1/dt tidak mampu memenuhi kebutuhan air bersih seiring dengan pertumbuhan jumlah penduduk hingga tahun 2014.
\end{abstract}

Kata kunci: Proyeksi, Debit, Kapasitas, Kebutuhan Air Bersih

\section{Pendahuluan}

Air bersih merupakan salah satu unsur lingkungan yang sangat penting bagi kelangsungan hidup manusia. Air bersih yang dibutuhkan manusia sebagai kebutuhan hidupnya harus memenuhi berbagai persyaratan, terutama kualitas, kuantitas, kontinuitas dan aspek kesehatan. Untuk penyediaan kebutuhan air bersih yang memenuhi berbagai persyaratan maka dengan bantuan dari pihak luar negeri (Oxfam), Pemerintah bekerja sama dengan PDAM membangun suatu bangunan pengolahan air bersih di desa Geudong dengan nama IPA Bantuan Oxfam. Instalasi Pengolahan Air (IPA) Bantuan Oxfam yang berkapasitas $20 \mathrm{l} / \mathrm{dt}$ di bangun bulan Januari tahun 2008. IPA Bantuan Oxfam ini di tempatkan di desa Geudong yang wilayah pelayanannya mencakup dua kecamatan yaitu Samudera dan Meurah Mulia dengan jumlah penduduknya sebesar 42436 jiwa. Sumber Air 
baku untuk IPA Bantuan Oxfam bersumber dari Sungai Krueng Pase. Sungai Krueng Pase terletak di Kecamatan Meurah Mulia Kabupaten Aceh Utara Provinsi Nanggroe Aceh Darussalam. Air Krueng Pase bersumber dari Danau Laut Tawar dan bermuara di Selat Malaka. Krueng Pase memiliki daerah tangkapan (Daerah Aliran Sungai) yang tidak terlalu luas $\pm 420 \mathrm{~km}^{2}$. Namun dengan trase sungai yang panjang $\pm 90,04 \mathrm{~km}^{2}$ dan mempunyai kemiringan ratarata sungai $0.000390 \mathrm{~mm}$. Pengembangan sistem penyediaan air bersih yang diharapkan dapat terpenuhi namun apabila hal ini tidak direncanakan mulai sekarang maka kondisi kebutuhan air bersih pada tahun 2017 akan menjadi sangat kritis untuk itu perlu adanya pemikiran untuk pemenuhan kebutuhan air bersih pada masa yang akan datang. Adapun tujuan dari penelitian ini untuk menganalisa berapa besar kebutuhan air bersih yang dipengaruhi oleh pertumbuhan jumlah penduduk serta diamati dari ketersediaan sumber air bakunya, dan mampukah IPA Bantuan Oxfam berkapasitas $20 \mathrm{l} / \mathrm{dt}$ melayani kebutuhan air bersih untuk masyarakat di wilayah kecamatan Samudera dan Meurah Mulia hingga tahun 2017. Penelitian ini diharapkan dapat menjadi salah satu bahan pertimbangan Pemerintah serta Perusahaan PDAM Tirta Mon Pase untuk pendistribusian kebutuhan air bersih di wilayah Kecamatan Samudera dan Meurah Mulia, sehingga kebutuhan air bersih untuk masyarakat tercukupi serta tidak terjadi kelangkaan akan air bersih pada masa yang akan datang.

\section{Tinjauan Kepustakaan}

\subsection{Intesitas hujan dan curah hujan}

Menurut Suyono (1976), intensitas hujan adalah curah hujan yang mungkin turun. Untuk curah hujan harian dapat dihitung dengan hanya menggunakan curah hujan 1 jam dan curah hujan 24 jam yakni data curah hujan yang biasanya dapat diperoleh dengan mudah. Ketinggian hujan yang terjadi pada suatu kurun waktu air hujan terkosentrasi.

Menurut Wesli (2008), intensitas hujan ialah jumlah hujan yang dinyatakan dalam tinggi hujan atau volume hujan tiap satuan waktu. Biasanya intesitas hujan dihubungkan dengan durasi hujan jangka pendek, misalnya 5 menit, 30 menit, 60 menit dan perjam. Data curah hujan jangka pendek ini hanya dapat diperoleh dengan menggunakan alat pencatat hujan otomatis. Di Indonesia alat ini sangat sedikit, yang banyak adalah alat pencatat hujan biasa yang mengatur hujan 24 jam atau disebut dengan hujan harian. Apabila yang tersedia hanya dengan hujan harian ini, maka intensitas hujan dapat diestimasi dengan menggunakan rumus Mononobe seperti berikut ini :

$$
\mathrm{I}=\frac{R_{24}}{24} \cdot\left(\frac{24}{T c}\right)^{2 / 3}
$$

Menurut Wesli (2008), yang dimaksud dengan curah hujan rencana adalah hujan harian maksimum yang akan digunakan untuk menghitung intensitas hujan, kemudian intensitas ini digunakan untuk mengestimsi debit rencana. Untuk menghitung besarnya curah hujan rencana berdasarkan data yang sudah ada dapat dilakukan dengan menggunakan berbagai cara, akan tetapi dalam penulisan tugas akhir ini hanya digunakan metode Gumbel dan metode Haspers. 
1. Metode Gumbel

Metode Gumbel merupakan suatu cara yang paling sering digunakan dalam perhitungan curah hujan rencana. Untuk menghitung besarnya curah hujan yang terjadi dapat digunakan persamaan sebagai berikut :

$$
X_{\mathrm{t}}=\mathrm{X}_{\mathrm{a}}+\mathrm{k} \cdot \mathrm{S}_{\mathrm{x}}
$$

Harga faktor frekuensi tergantung dari banyaknya data yang dianalisa, dan dari periode ulang yang dikehendaki sehingga dapat dirumuskan sebagai berikut :

$$
\begin{aligned}
& \mathrm{k}=\frac{Y_{t}-Y_{n}}{S_{n}} \ldots \ldots \ldots \ldots \ldots \ldots \ldots \ldots \ldots \ldots \ldots \ldots \ldots \ldots \ldots \ldots \ldots \ldots \ldots \\
& \mathrm{Y}_{\mathrm{t}}=-\left[0,834+2,303 \log \frac{T}{T-1}\right]
\end{aligned}
$$

Dari persamaan (2.2) dapat didistribusikan ke persamaan (2.3) menjadi :

$$
\mathrm{X}_{\mathrm{t}}=\mathrm{X}_{\mathrm{a}}+\frac{Y_{t}-Y_{n}}{S_{n}} \cdot \mathrm{S}_{\mathrm{x}}
$$

Untuk standar deviasi dapat digunakan rumus sebagai berikut :

$$
\begin{aligned}
& \mathrm{s}=\sqrt{\frac{\sum\left(X i-X_{a}\right)^{2}}{n-1}} \ldots \sqrt{\frac{\sum(X i)^{2}-X_{a} \sum\left(X_{i}\right)^{2}}{n-1}}
\end{aligned}
$$

2. Metode Haspers

Untuk menghitung curah hujan rencana dapat juga dihitung mengunakan metode Haspers dengan rumus sebagai berikut :

$$
\begin{aligned}
\mathrm{R}_{\mathrm{t}} & =\bar{R}+\alpha \cdot \mathrm{k}_{\mathrm{x}} \\
\alpha & =\frac{R_{n}-\bar{R}}{U_{n}+1} \ldots . . .
\end{aligned}
$$

\subsection{Koefisien pengaliran dan koefisien tampungan}

Menurut Suyono (1976), koefisien aliran adalah besarnya puncak limpasan dibagi dengan intensitas curah hujan rata-rata selama waktu tiba dari banjir yang dikalikan dengan luas daerah pengaliran. Menurut Wesli (2008), koefisen aliran (runoff coefficient) adalah perbandingan antara jumlah air hujan yang mengalir atau melimpas di atas permukaan tanah (surface runoff) dengan jumlah air hujan yang jatuh dari atmosfir. Nilai koefisien penagaliran berkisar antara 0 (nol) sampai dengan 1 (satu) dan tergantung dari jenis tanah, jenis vegetasi dan konstruksi yang ada di permukaan tanah.

Nilai koefisien aliran $=\frac{\text { luas..kawasan }}{\text { daerah..aliran }} \mathrm{x}$ koefisen aliran kawasan

Menurut Wesli (2008), daerah yang memiliki lekukkan untuk menampung air hujan relatif mengalirkan lebih sedikit air hujan dibandingkan dengan daerah yang tidak memiliki lekukan yang sama sekali. Efek tampungan oleh lekukan ini terhadap debit rencana diperkirakan dengan koefisien tampungan yang diperoleh dengan rumus berikut ini :

Studi Analisa Kapasitas Debit Terhadap Kebutuhan Air Bersih Proyeksi Tahun 20092014 Pada IPA Bantuan AXFAM (PDAM Tirta Mon Pase) Kabupaten Aceh Utara- 


$$
\mathrm{Cs}=\frac{2 T c}{2 T c+T d}
$$

\subsection{Waktu Konsentrasi}

Menurut Wesli (2008), waktu yang dibutuhkan oleh sebuah titik hujan yang jatuh di tempat terjauh untuk mengalir diatas tanah ke tempat pengukuran disebut waktu kosentrasi. Waktu kosentrasi ditentukan menggunakan persamaan sebagai berikut :

$$
\mathrm{Tc}=\mathrm{To}+\mathrm{Td}
$$

Harga To dapat diperoleh dari rumus - rumus empiris, salah satunya adalah rumus Kirpich, seperti berikut ini :

$$
\text { To }=0,0195\left(\frac{L o}{\sqrt{S o}}\right)^{0,77}
$$

Atau dengan rumus berikut ini :

$$
\text { To }=\left(\frac{2}{3} \cdot 3,28 \cdot L o \frac{n}{\sqrt{S o}}\right)^{0,77}
$$

Harga Td ditentukan oleh panjang saluran yang dilalui dan kecepatan aliran di dalam saluran, seperti ditunjukan oleh rumu seagai berikut ini :

$$
\mathrm{Td}=\frac{1 . L_{1}}{3600 . V}
$$

\subsection{Debit Andalan}

Menurut Wiyono (2000), debit andalan adalah debit minimum yang tersimpan di sungai dan dapat diandalkan untuk reabilitas tertentu, untuk keperluan irigasi dan pengambilan sumber air baku, biasanya digunakan debit andalan dengan reabilitas yang lebih tinggi, yaitu sekitar $80 \%$ sampai $90 \%$.

Menurut Suyono (1976), untuk menghitung debit andalan digunakan rumus rasional. Rumus ini banyak digunakan untuk sungai-sungai biasa dengan daerah pengaliran yang luas dan juga untuk perencanaan drainase daerah pengaliran yang relatif sempit. Rumus yang sering digunakan adalah sebagai berikut :

$$
\mathrm{Q}=0,278 \times \mathrm{C} \times \mathrm{Cs} \times \mathrm{I} \times \mathrm{A}
$$

\subsection{Pengertian Air Bersih dan Air Minum}

Air bersih adalah air yang digunakan untuk keperluan sehari-hari dan akan menjadi air minum setelah dilakukan pengolahan. Sebagai batasnya air bersih adalah air yang memenuhi persyaratan bagi sistem penyediaan air minum. Persyaratan tersebut juga memperhatikan pengamanan terhadap sistem distribusi air bersih sampai dengan konsumen. Sedangkan air minum adalah air yang kualitasnya memenuhi persyaratan kesehatan yang dapat diminum (air mineral).

Dalam memilih sumber air baku air bersih, maka harus diperhatikan persyaratan utamanya yang meliputi kualitas, kontinuitas dan biaya yang murah dalam proses pengambilan sampai pada proses pengolahannya. Beberapa sumber air baku yang dapat digunakan untuk penyediaan air bersih dikelompokan sebagai berikut, Anonim (1997): Air hujan, Air permukaan, Air tanah, Mata air 


\subsection{Proyeksi Jumlah Penduduk}

Dari data stastistik penduduk yang diperoleh dari kantor BPS dapat diketahui pertumbuhan penduduk yang digunakan sebagai dasar untuk melakukan proyeksi pertumbuhan penduduk pada tahun mendatang, dihitung dengan metode Geometrik, metode Arithmatik dan metode Least Square (Anonim, 2002) :

Metode 1 (metode Geometrik)

$$
\mathrm{P}_{\mathrm{n}}=\mathrm{P}_{\mathrm{o}}(1+\mathrm{r})^{\mathrm{n}}
$$

Metode 2 (Dengan cara Metode Arithmatik)

$$
\begin{aligned}
& \mathrm{P}=\mathrm{Pn} \mathrm{Po}+\mathrm{Ka}(\mathrm{Tn}-\mathrm{To}) \\
& \mathrm{Ka}=(\mathrm{Pa}-\mathrm{P} 1):(\mathrm{T} 2-\mathrm{T} 1)
\end{aligned}
$$

Metode 3 (Dengan cara Metode Least Square)

$$
\breve{\mathrm{y}}=\mathrm{a}+\mathrm{bX}
$$

Adapun persamaan a dan $\mathrm{b}$ adalah sebagai berikut :

$$
\begin{aligned}
& \mathrm{a}=\frac{\sum Y \cdot \sum X^{2}-\sum X \cdot \sum X Y}{n \cdot \sum X^{2}-\left(\sum X\right)^{2}} \\
& \mathrm{~b}=\frac{n \cdot \sum Y \cdot X-\sum X \cdot \sum Y}{n \cdot \sum X^{2}-\left(\sum X\right)^{2}} \ldots \ldots . .
\end{aligned}
$$

Bila koefisien $\mathrm{b}$ telah dihitung terlebih dahulu, maka konstanta a dapat ditentukan dengan persamaan lain yaitu :

$$
\mathrm{a}=\bar{Y} \cdot b \bar{X}
$$

Dimana $\bar{Y}$ dan $\bar{X}$ maisng-masing adalah rata-rata untuk variabel X dan Y. Untuk menentukan pilihan rumus proyeksi jumlah penduduk yang akan digunakan dengan hasil perhitungan yang paling mendekati kebenaran harus dilakukan analisa dengan menghitung standar deviasi. Rumus standar deviasi adalah:

$$
\begin{array}{ll}
\mathrm{s}=\sqrt{\frac{\sum(X i-\bar{X})^{2}}{n-1}} & \text { untuk } \mathrm{n}>20 . \\
\mathrm{s}=\sqrt{\frac{\sum(X i-\bar{X})^{2}}{n}} & \text { untuk } \mathrm{n}=20
\end{array}
$$

\subsection{Proyeksi Kebutuhan Air Bersih}

Proyeksi kebutuhan air bersih diperhitungkan dengan memperhatikan beberapa faktor yang mempengaruhi besarnya kebutuhan air bersih, Anonim (2006) yaitu : Pertambahan jumlah penduduk; Tingkat kehidupan dan aktifitas penduduk; Keadaan iklim daerah pelayanan; Rencana daerah pelayanan; Keadaan sosial ekonomi masyarakat setempat.

Berdasarkan pendekatan-pendekatan tersebut di atas, maka dalam memperkirakan kebutuhan air di masa mendatang akan dibagi dalam beberapa klasifikasi kebutuhan air yaitu :

1. Kebutuhan domestik adalah kebutuhan air untuk keperluan rumah tangga. Jumlah kebutuhannya didasarkan pada banyaknya penduduk, persentase penduduk yang dilayani dan cara pembagian air yaitu sambungan melalui kran 
umum / hidran umum. Untuk menghitung kebutuhan Domestik digunakan persamaan di bawah ini, Anonim (2002) :

QD = P X Cair

2. Kebutuhan Non Domestik adalah pelayanan air untuk kebutuhan kegiatan penujang kota, yang terdiri dari kegiatan komersial yang berupa industri, perkantoran, pelabuhan, dan kegiatan sosial seperti sekolah, rumah sakit, dan tempat ibadah. Untuk menghitung jumlah kebutuhan air total digunakan persamaan sebagai berikut :

Qtotal $=$ QD + QND

3. Kehilangan air atau "Non Reveneu Water" (NRW) adalah selisih antara produksi air dengan air yang tercatat diameter langganan.

Untuk mendapatkan data fluktuasi pemakaian air jam perjam secara tepat untuk keperluan perencanaan bangunan pengolahan air bersih, maka cara yang ditempuh umumnya adalah dengan membandingkan kota (daerah) yang direncanakan dengan kota (daerah) yang telah direncanakan (telah mempunyai data fluktuasi pemakaian air jam perjam), Anonim (1997).

\subsection{Sistem Distribusi Air Bersih}

\subsubsection{Definisi sistem distribusi air bersih}

Sistem distribusi air bersih adalah pendistribusian atau pembagian air melalui sistem perpipaan dari bangunan pengolahan (reservoir) ke daerah pelayanan (konsumen).

\subsubsection{Pipa Distribusi}

Pipa distribusi adalah pipa yang berfungsi membawa air ke konsumen yang terdiri dari :

1. Pipa induk yaitu pipa utama pembawa air yang akan dibagikan ke pada konsumen.

2. Pipa cabang yaitu pipa cabang dari pipa induk.

3. Pipa dinas yaitu pipa pembawa air yang langsung melayani konsumen.

\subsubsection{Tipe Pengaliran}

Tipe pengaliran sistem distribusi air bersih meliputi aliran garavitasi dan aliran secara pemompaan. Tipe pengaliran secara gravitasi diterapkan bila tekanan air pada titik terjauh yang diterima konsumen masih mencukupi. Jika kondisi ini tidak terpenuhi maka pengaliran harus menggunakan sistem pemompaan.

\subsubsection{Pola Jaringan}

Macam pola jaringan sistem distribusi air bersih terdiri dari sistem cabang adalah sistem pendistribusian air bersih yang bersifat terputus membentuk cabang-cabang sesuai dengan daerah pelayanan, sistem loop adalah sistem perpipaan melingkar dimana ujung pipa yang satu bertemu kembali dengan ujung pipa yang lain.

\subsection{Proses Pengolahan Air}

Menurut Sutrisno (1987), yang dimaksud dengan pengolahan adalah usahausaha teknis yang dilakukan untuk mengubah sifat-sifat suatu zat. Hal ini penting artinya bagi air minum, karena dengan adanya pengolahan ini, maka akan didapatkan suatu air minum yang telah ditentukan. Menurut Sutrisno (1987), 
adapun unit-unit pengolahan air minum terdiri dari: a) Bangunan penangkap air, b) Bangunan pengendap pertama, c) Pembuluh koagulant, d) Bangunan pengaduk cepat, d) Bangunan pembentuk floc, e) Bangunan pengendap kedua, f) Bangunan penyaring, g) Reservoir dan h) Pemompaan.

\subsection{Aliran Melalui Pipa}

Menurut Triatmodjo (1996), pipa adalah saluran tertutup yang biasanya berpenampang lingkaran dan digunakan untuk mengalirkan fluida dengan tampang aliran penuh. Apabila zat cair di dalam pipa tidak penuh maka aliran termasuk dalam aliran saluran terbuka. Pada zat cair yang mengalir di dalam bidang batas (pipa, saluran terbuka atau bidang datar) akan terjadi tegangan geser dan gradien kecepatan pada seluruh medan aliran karena adanya kekentelan. Tegangan geser tersebut akan menyebabkan terjadinya kehilangan selama pengaliran. Untuk menghitung kehilangan tenaga aliran di gunakan persamaan:

$$
\mathrm{h}_{\mathrm{f}} \quad=\mathrm{f} \frac{L}{D} \frac{V^{2}}{2 g}
$$

\subsection{Angka Reynolds}

Menurut Reynolds (1884), ada tiga faktor yang mempengaruhi keadaan aliran yaitu kekentalan kinematik zat cair u (mu), rapat masa zat cair $\rho$ (rho), dan diameter pipa D. Angka Reynolds mempunyai bentuk berikut ini :

$$
\operatorname{Re}=\frac{V}{\frac{u}{\rho . D}}=\frac{\rho \cdot d \cdot V}{\rho}
$$

Atau

$$
\operatorname{Re}=\frac{V \cdot D}{v}
$$

Berdasarkan percobaan pada aliran dalam pipa, Reynolds menetapkan bahwa untuk angka Reynolds di bawah 2000, gangguan aliran dapat direndam oleh kekentalan zat cair, dan aliran pada kondisi tersebut adalah laminer. Aliran akan turbulen apabila angka Reynolds berada lebih besar 4000. Apabila angka Reynolds berada diantara kedua nilai tersebut $(2000<\operatorname{Re}<4000)$ aliran adalah transisi. Angka Reynolds pada kedua nilai diatas $(\operatorname{Re}=2000$ dan $\operatorname{Re}=4000)$ disebut dengan batas kritik bawah dan atas.

\subsection{Koefisien Gesekan}

Kehilangan tenaga selama pengaliran melalui pipa tergantung pada koefisien gesekan Darcy-Weisbach f. Blasius memberikan persamaan tahanan gesek untuk pipa halus pada batasan angka Reynolds tertentu. Berdasarkan penelitian yang dilakukan Blasius, dia mengemukakan rumus gesekan $f$ untuk pipa halus dalam bentuk :

$$
\mathrm{f} \quad=\frac{0,316}{\operatorname{Re}^{0.25}}
$$

\subsection{Tegangan Geser Pada Dinding}

Menghitung tegangan geser pada dinding dapat dihitung dengan menggunakan rumus berikut :

Studi Analisa Kapasitas Debit Terhadap Kebutuhan Air Bersih Proyeksi Tahun 20092014 Pada IPA Bantuan AXFAM (PDAM Tirta Mon Pase) Kabupaten Aceh Utara- 


$$
\tau_{\mathrm{o}} \quad=\frac{f}{8} \cdot \rho \cdot \mathrm{V}^{2}
$$

Kecepatan pada sumbu pipa dihitung dengan rumus :

$$
\frac{V}{V_{*}}=5,75 \log \frac{V_{*} \cdot V}{V}+5,5
$$

\subsection{Pipa dengan Pompa}

Menurut Triatmodjo (1996), jika pompa menaikan zat cair dari kolam satu ke kolam lain dengan selisih muka air Hs, seperti yang ditunjukan pada gambar 2.1 maka daya yang digunakan oleh pompa untuk menaikan zat cair setinggi $\mathrm{Hs}$ adalah sama dengan tinggi $\mathrm{H}_{\mathrm{s}}$ ditambah dengan kehilangan tenaga selama pengaliran dalam pipa tersebut. Kehilangan tenaga adalah ekivalen dengan penambahan tinggi elevasi, sehingga efeknya sama dengan jika pompa menaikan zat cair setinggi $\mathrm{H}=\mathrm{H}_{\mathrm{s}}+\sum \mathrm{hf}$. Dalam gambar tersebut tinggi kecepatan diabaikan sehingga garis tenaga berimpit dengan garis tekanan.

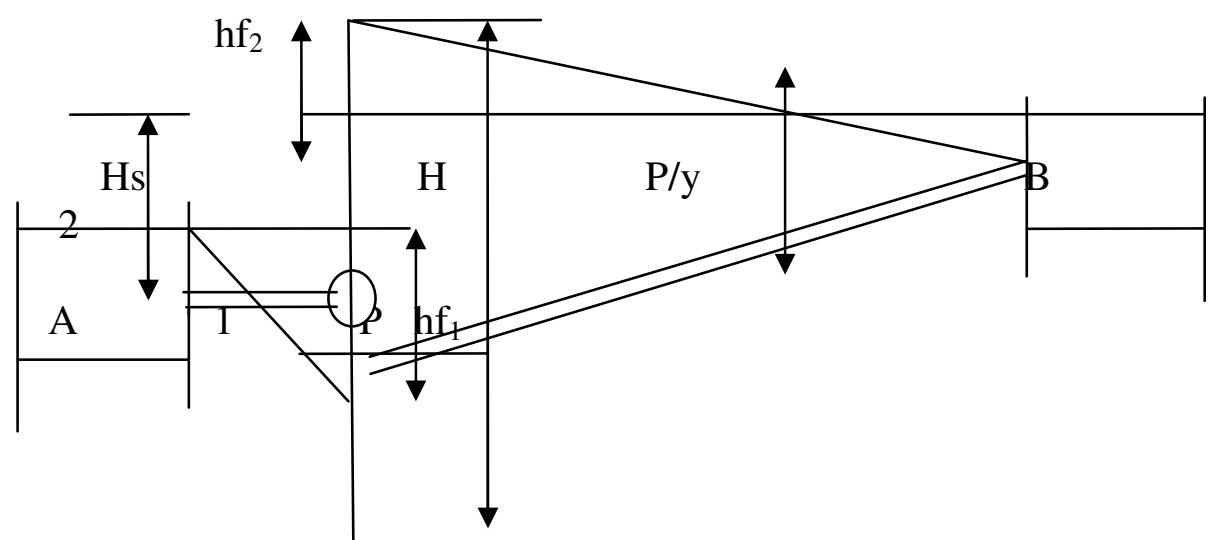

Gambar 2.1 Pipa dengan pompa

Kehilangan tenaga terjadi pada pengaliran pipa 1 dan 2 yaitu sebesar $\mathrm{hf}_{1}$ dan $\mathrm{hf}_{2}$. Pada pipa 1 yang merupakan pipa isap, garis tenaga (dan tekanan) menurun sampai di bawah pipa. Bagian pipa di mana garis tekanan di bawah sumbu pipa mempunyai tekanan negatif. Sedang pipa 2 merupakan pipa tekan. Daya yang diperlukan pompa untuk menaikan zat cair :

$$
\mathrm{D}=\frac{Q \cdot H \cdot \gamma}{\eta}(\mathrm{kgf} \cdot \mathrm{m} / \mathrm{d})
$$

Atau

$$
\mathrm{D}=\frac{Q \cdot H \cdot \gamma}{75 \cdot \eta}(\mathrm{hp})
$$

Dengan $\eta$ adalah efisiensi pompa. Pada pemakaian pompa, efisiensi pompa digunakan sebagai pembagi dalam rumus daya pompa.

\subsection{Rumus Empiris}

Menurut Triatdmodjo (1996), di dalam praktek, faktor penting dalam studi hidrolika adalah kecepatan V atau debit aliran Q. Dalam hitungan praktis, rumus yang banyak di gunakan adalah persamaan kontiunitas, $\mathrm{Q}=\mathrm{A}$.V dengan $\mathrm{A}$ adalah tampang aliran. 


\section{Metode Penelitian}

Dalam melakukan penelitian ini digunakan metodologi untuk pengumpulan dan pengolahan data. Berdasarkan data yang ada maka dilakukan perhitungan intensitas hujan, koefisien tampungan, debit andalan sungai, proyeksi jumlah penduduk, serta proyeksi kebutuhan air bersih.

\subsection{Intensitas Hujan (I)}

Hujan terjadi secara alamiah, dimana intensitas hujan tidak dapat kita tentukan atau kita atur secara pasti. Namun kita dapat melakukan perkiraan berdasarkan pencatatan data-data hujan harian sebelumnya, oleh karena itu dalam menghitung besarnya intensitas hujan yang terjadi maka penulis menggunakan rumus Mononobe yang tercantum pada persamaan 2.1.

\subsection{Curah Hujan Rencana}

Curah hujan rencana dihitung berdasarkan data curah hujan harian minimum yang akan digunakan untuk menghitung intensitas hujan. Berdasarkan intensitas hujan akan dilakukan estimasi terhadap debit banjir rencana yang dihitung berbanding lurus dengan koefisien tampung pada suatu daerah aliran. Metode yang digunakan dalam perhitungan curah hujan rencana adalah metode Gumbel dan metode Haspers

\subsection{Koefisien Aliran (C)}

Koefisien aliran berarti perbandingan antara jumlah air hujan yang mengalir atau melimpas diatas permukaan tanah dengan jumlah air hujan yang jatuh dari atmosfir. Untuk menentukan koefisien aliran perlu mengetahui nilai koefisien itu sendiri. Nilai koefisien ini berkisar antara 0 sampai dengan 1 dan bergantung pada jenis tanah, jenis vegetasi dan konstruksi yang ada di permukaan tanah. Ada banyak penelitian yang telah dilakukan untuk menentukan nilai koefisien aliran.

\subsection{Koefisien Tampungan (Cs)}

Daerah yang memiliki lekukan untuk menampung air hujan relatif mengalirkan sedikit air hujan dibandingkan dengan daerah yang tidak memiliki lekukan sama sekali. Untuk mengetahui nilai koefisien tampungan digunakan persamaan 2.11 pada halaman 7 . Akan tetapi sebelumnya, perlu diketahui terlebih dahulu waktu kosentrasi (Tc)

\subsection{Debit Andalan (Q)}

Debit andalan adalah debit minimum yang tersimpan di sungai dan dapat diandakan untuk reabilitas tertentu, untuk keperluan irigasi, pengambilan sumber air baku, dll. Untuk menghitung debit andalan dapat dihitung dengan menggunkan rumus rasional atau persamaan 2.16 pada halaman 9 .

\subsection{Proyeksi Jumlah Penduduk (Pn)}

Untuk memproyeksi atau memperkirakan pertumbuhan jumlah penduduk di wilayah Kecamatan Samudera dan Meurah Mulia pada masa yang akan datang, akan dihitung dengan menggunakan pendekatan tiga metoda, yaitu metoda Geometrik, metoda Arithmatik, dan metoda Least Square, dari ketiga metoda ini 
akan dihitung standar deviasinya. Metoda perhitungan yang paling tepat adalah metoda yang memberikan harga standar deviasi terkecil.

\subsection{Proyeksi Kebutuhan Air Bersih (Qtotal)}

Proyeksi kebutuhan air bersih dihitung berdasarkan pertumbuhan jumlah penduduk. Proyeksi kebutuhan air bersih di bagi dalam dua bagian yaitu kebutuhan domestik dihitung menggunakan persamaan 2.26 pada halaman 15 dan kebutuhan non domestik yang dapat dilihat pada tabel 2.4 Pemakaian air rata-rata untuk kebutuhan non domestik

\subsection{Aliran Melalui Pipa}

Untuk menghitung kehilangan tenaga aliran melalui pipa yang disebabkan karena gesekan maka akan dihitung dengan persamaan 2.28 pada halaman 22 . Untuk menghitung daya pompa yang dipengaruhi oleh tinggi elevasi selisih muka air ditambah dengan kehilangan tenaga selama pengaliran dalam pipa digunakan persamaan 2.35

\section{Hasil dan Pembahasan}

Pokok pembahasan meliputi hasil dan pengolahan data tinggi curah hujan, data hidrologi, pertumbuhan jumlah penduduk, dan kebutuhan air.

\subsection{Hasil}

\subsubsection{Curah Hujan Rencana}

Tidak tersedianya data aliran sungai berupa debit andalan yang pernah terjadi pada tahun-tahun sebelumnya, merupakan suatu masalah yang sering dijumpai. Dalam menggunakan data curah hujan untuk memperkirakan besarnya debit andalan, digunakan anggapan bahwa hujan terbesar merata ke seluruh daerah dengan periode ulang tertentu akan tetapi lebih dahulu harus menghitung harga rata-rata dan standar deviasi.

Untuk mencari debit andalan sungai terlebih dahulu ditentukan stasiunstasiun hujan yang mewakili daerah aliran yaitu stasiun-stasiun yang terletak di dalam daerah aliran yang bersangkutan. Jika stasiun-stasiun yang dimaksud tidak ada, maka dapat dipakai dari stasiun-stasiun yang terdekat dengan daerah aliran tersebut. Dalam penulisan ini, penulis menggunakan data curah hujan dari stasiun Peunteut, stasiun Samudera dan stasiun Lhoksukon untuk periode ulang 5, 10, 20, 50, dan 100 tahun yaitu dengan menggunakan metode Haspers. Untuk BPP Peunteut $\mathrm{R}_{(5)}=847.254 \mathrm{~mm}, \mathrm{R}_{(10)}=835.973 \mathrm{~mm}, \mathrm{R}_{(20)}=719.666 \mathrm{~mm}, \mathrm{R}_{(50)}=$ $573.563 \mathrm{~mm}, \mathrm{R}_{(100)}=497.948 \mathrm{~mm}$. Untuk BPP Samudera $\mathrm{R}_{(5)}=585.412 \mathrm{~mm}$, $\mathrm{R}_{(10)}=577.434 \mathrm{~mm}, \mathrm{R}_{(20)}=497.096 \mathrm{~mm}, \mathrm{R}_{(50)}=396.179 \mathrm{~mm}, \mathrm{R}_{(100)}=343.972$ mm. Untuk BPP Lhoksukon $\mathrm{R}_{(5)}=563.9 \mathrm{~mm}, \mathrm{R}_{(10)}=556.209 \mathrm{~mm}, \mathrm{R}_{(20)}=$ $478.830 \mathrm{~mm}, \mathrm{R}_{(50)}=381.621 \mathrm{~mm}, \mathrm{R}_{(100)}=338.084 \mathrm{~mm}$.

\subsubsection{Intensitas hujan}

Intensitas hujan yang terjadi diambil berdasarkan perhitungan curah hujan yang memiliki nilai maksimum adalah BPP Peunteut dengan periode ulang 5,10 , $20,50,100$ tahun yaitu $\mathrm{I}_{5}=209.34 \mathrm{~mm} / \mathrm{jam}, \mathrm{I}_{10}=206.554 \mathrm{~mm} / \mathrm{jam}, \mathrm{I}_{20}=177.907$ $\mathrm{mm} / \mathrm{jam}, \mathrm{I}_{50}=141.789 \mathrm{~mm} / \mathrm{jam}, \mathrm{I}_{100}=118.647 \mathrm{~mm} / \mathrm{jam}$. 


\subsubsection{Debit Andalan}

Tidak tersedianya data aliran sungai berupa debit andalan yang pernah terjadi, maka debit andalan sungai dapat dihitung dengan menggunakan rumus berdasarkan data curah hujan, nilai koefisien aliran (C), nilai koefisien tampungan (Cs), intensitas hujan (I), dan luas aliran (A). Debit andalan yang digunakan penulis untuk periode ulang 5 tahun diambil dari hasil perhitungan yaitu sebesar $8967.205 \mathrm{~m}^{3} /$ det.

\subsection{Pembahasan} berikut :

Adapun yang menjadi pembahasan dalam penelitian ini adalah sebagai

\subsubsection{Proyeksi Jumlah Penduduk}

Untuk mengetahui dan memperkirakan besarnya jumlah penduduk pada masa mendatang diperlukan data-data mengenai besarnya jumlah penduduk pada tahun tahun sebelumnya. Pada data BPS Kabuaten Aceh Utara telah didapat data pada tahun 2003 - 2007, yang mana hasilnya adalah dibawah ini :

Tabel 4.1 Data Penduduk

\begin{tabular}{|c|c|c|}
\hline \multirow{2}{*}{ TAHUN } & \multicolumn{2}{|c|}{ JUMLAH PENDUDUK } \\
\cline { 2 - 3 } & KEC. MEURAH MULIA & KEC. SAMUDERA \\
\hline 2003 & 16582 & 21060 \\
\hline 2004 & 16253 & 21908 \\
\hline 2005 & 16421 & 21466 \\
\hline 2006 & 16443 & 21880 \\
\hline 2007 & 16766 & 22508 \\
\hline
\end{tabular}

Sumber : BPS Kabupaten Aceh Utara

Proyeksi pertumbuhan jumlah penduduk sampai dengan tahun 2014 dapat dilihat pada tabel 4.2 di bawah ini.

Tabel 4.2 Pertumbuhan Jumlah Penduduk

\begin{tabular}{|c|c|c|}
\hline \multirow{2}{*}{ TAHUN } & \multicolumn{2}{|c|}{ JUMLAH PENDUDUK } \\
\cline { 2 - 3 } & KEC. MEURAH MULIA & KEC. SAMUDERA \\
\hline 2008 & 16815 & 22891 \\
\hline 2009 & 16863 & 23280 \\
\hline 2010 & 16912 & 23675 \\
\hline 2011 & 16961 & 24078 \\
\hline 2012 & 17010 & 24487 \\
\hline 2013 & 17060 & 24904 \\
\hline 2014 & 17109 & 25327 \\
\hline
\end{tabular}

\subsubsection{Proyeksi Kebutuhan Air Bersih}

Kebutuhan air bersih dibagi menjadi dua yaitu kebutuhan air domestik dan kebutuhan air non domestik. Kebutuhan air domestik adalah kebutuhan air untuk keperluan rumah tangga yang jumlah kebutuhannya didasarkan pada banyaknya penduduk. Sedangkan untuk kebutuhan air non domestik adalah kebutuhan air 
untuk kebutuhan kegiatan penunjang kota, yang terdiri dari kegiatan komersial dan kegiatan sosial. Untuk memenuhi kebutuhan air domestik di kecamatan Meurah Mulia dan Samudera sebesar 1026540 liter/hari dan 1519620 liter/hari, sedangkan untuk kebutuhan air non domestik di kecamatan Meurah Mulia dan Samudera sebesar 3459110 liter/hari dan 3723710 liter/hari.

Tabel 4.3 Kebutuhan Air Domestik

\begin{tabular}{|c|c|c|}
\hline \multirow{2}{*}{ TAHUN } & \multicolumn{2}{|c|}{ KEBUTUHAN AIR DOMESTIK (1/dt) } \\
\cline { 2 - 3 } & KEC. MEURAH MULIA & KEC. SAMUDERA \\
\hline 2008 & 1008900 & 1373460 \\
\hline 2009 & 1011780 & 1396800 \\
\hline 2010 & 1014720 & 1420500 \\
\hline 2011 & 1017660 & 1444680 \\
\hline 2012 & 1020600 & 1469220 \\
\hline 2013 & 1023600 & 1494240 \\
\hline 2014 & 1026540 & 1519620 \\
\hline
\end{tabular}

\subsubsection{Aliran Melalui Pipa}

Setelah melakukan perhitungan aliran melalui pipa maka diperoleh datadata sebagai berikut.

- Untuk kapasitas distribusi 20 1/dt digunakan Pipa Diameter $250 \mathrm{~mm}=8$ ",

Kecepatan aliran, V

$=1.019 \mathrm{~m} / \mathrm{d}$

Angka Reynolds, Re

$$
=12,74 \times 10^{6}
$$

Koefisien gesekan, $\mathrm{f}$

$=0,0167$

Kehilangan tenaga aliran, $\mathrm{h}_{\mathrm{f}} \quad=1,416 \mathrm{~m}$

tegangan geser pada dinding, $\tau_{\mathrm{o}}=2,167 \mathrm{~N} / \mathrm{m}^{2}$

kecepatan geser, $V_{*} \quad=0,0465 \mathrm{~m} / \mathrm{d}$

Kecepatan pada sumbu pipa, $\mathrm{V}=\mathrm{Vmaks}=0.572 \mathrm{~m} / \mathrm{dt}$

Daya pompa, $\mathrm{D} \quad=7.833 \mathrm{hp}$

- Untuk kapasitas distribusi 150 1/dt digunakan Pipa Diameter 300 mm = 12',

Kecepatan aliran, $\mathrm{V} \quad=2.831 \mathrm{~m} / \mathrm{d}$

Angka Reynolds, Re $\quad=42,45 \times 10^{6}$

Koefisien gesekan, $\mathrm{f} \quad=0,0123$

Kehilangan tenaga aliran, $\mathrm{h}_{\mathrm{f}} \quad=6,691 \mathrm{~m}$

tegangan geser pada dinding, $\tau_{\mathrm{o}}=12,322 \mathrm{~N} / \mathrm{m}^{2}$

kecepatan geser, $\mathrm{V}_{*} \quad=0,111 \mathrm{~m} / \mathrm{d}$

Kecepatan pada sumbu pipa, $\mathrm{V}=\mathrm{Vmaks}=0,393 \mathrm{~m} / \mathrm{dt}$

Daya pompa, $\mathrm{D} \quad=28.333 \mathrm{hp}$

\section{Kesimpulan}

Ada beberapa kesimpulan yang dapat diambil dari pembahasan yang dilakukan terhadap analisa kebutuhan air bersih yaitu :

1. Kebutuhan air bersih untuk kebutuhan masyarakat di wilayah Kecamatan Samudera diperoleh sebesar 5243330 liter/hari = 60,686 1/dt dan Kecamatan Meurah Mulia diperoleh sebesar 4485650 liter/hari = 51,917 l/dt.

2. Jumlah pertumbuhan penduduk pada tahun 2014 untuk pemenuhan kebutuhan air bersih di Kecamatan Samudera diperoleh sebesar 25327 jiwa dan jumlah 
pertumbuhan penduduk pada tahun 2014 di Kecamatan Meurah Mulia diperoleh sebesar 17109 jiwa.

3. Debit andalan Sungai Krueng Pase sebesar Q $=7.765,911 \mathrm{~m}^{3} / \mathrm{det}$.

4. Selisih kebutuhan air bersih yang dibutuhkan dengan kebutuhan air bersih yang tersedia pada IPA Bantuan Oxfam yaitu 92,603 1/dt.

5. Maka secara umum IPA Bantuan Oxfam yang berkapasitas $201 /$ dt tidak mampu memenuhi kebutuhan air bersih untuk lima tahun ke depan seiring dengan pertumbuhan jumlah penduduk di Kecamatan Samudera dan Kecamatan Meurah Mulia.

6. Semakin besar kecepatan aliran $\mathrm{V}$, dimensi pipa $\mathrm{A}$, dan debit aliran $\mathrm{Q}$, maka daya pompa yang diperlukan semakin besar pula.

\section{Daftar Kepustakaan}

1. Anonim, (2008), Aceh Utara Dalam Angka (2008), Penerbit Badan Pusat Statistik Kabupaten Aceh Utara, Aceh Utara.

2. Anonim, (2007), Buku Panduan Pengembangan Air Minum, Penerbit Direktorat Jendral Cipta Karya Departemen Pekerjaan Umum, Jakarta.

3. Anonim, (2006), Master Plan Sistem Penyediaan Air Minum PDAM Tirta Mon Pase, Penerbit Wahana Cipta Inti, Bandung.

4. Anonim, (1997), Rekayasa Lingkungan, Penerbit Guna Darma, Jakarata.

5. Anonim, (2002), Sistem Penyediaan Air Minum Perkotaan, Penerbit Departemen Permukiman dan Prasarana Wilayah, Jakarta.

6. Desmi, A., (2005), Studi Keandalan Sumber Air Danau Laut Tawar Pembangkit Listrik Tenaga Air (PLTA) Peusangan, Tesis, Unsyiah, Banda Aceh.

7. Sasongko, D., (1995), Teknik Sumber Daya Air, Penerbit Erlangga, Jakarta.

8. Soewarno, (1998), Hidrologi Pengukuran dan Pengolahan Data Aliran Sungai, Penerbit Nova, Jakarta.

9. Sutrisno, T., (1987), Teknologi Penyediaan Air Bersih, Penerbit Rineka Cipta, Jakarta.

10. Triatmodjo, B., (1996), Hidrolika II, Penerbit Beta Offset, Yogyakarta.

11. Wesli, (2008). Drainase Perkotaan, Penerbit Graha Ilmu, Yogyakarta. 